\title{
PENINGKATAN KEMAMPUAN PEMAHAMAN MATEMATIS MELALUI PEMBELAJARAN DENGAN STRATEGI THINK TALK WRITE (TTW) DI SEKOLAH DASAR
}

\author{
Siti Quratul Ain, Eva Astuti Mulyani \\ Pendidikan Guru Sekolah Dasar FKIP Universitas Islam Riau, \\ Pendidikan Guru Sekolah Dasar FKIP Universitas Riau \\ quratulain@edu.uir.ac.id, eva.amulyani@gmail.com
}

\begin{abstract}
ABSTRAK
Penelitian ini bertujuan untuk menelaah peningkatan kemampuan pemahaman matematis siswa melalui pembelajaran dengan strategi Think Talk Write. Penelitian ini merupakan penelitian quasi experiment dengan desain penelitian kelas eksperimen dan kelas kontrol the pretest-posttest. Kelas eksperimen memperoleh pembelajaran dengan strategi Think Talk Write dan kelas kontrol memperoleh pembelajaran dengan pembelajaran langsung. Populasi dalam penelitian ini adalah siswa kelas IV salah satu Sekolah Dasar Negeri di Kota Bandung. Sampel dalam penelitian ini adalah 50 siswa yang berasal dari dua kelas. Intrumen yang digunakan dalam pengumpulan data adalah tes kemampuan pemahaman matematis bentuk uraian. Data hasil penelitian berupa skor $\mathrm{N}$-gain yang dianalisis dengan menggunakan uji-independent t-test dan uji MannWhitney. Dari penelitian ini, diperoleh kesimpulan Peningkatan kemampuan pemahaman matematis siswa yang memperoleh pembelajaran dengan strategi Think Talk Write lebih baik daripada siswa yang memperoleh pembelajaran dengan pembelajaran langsung.
\end{abstract}

Kata kunci : Pemahaman Matematis, strategi Think Talk Write dan pembelajaran langsung.

\begin{abstract}
This study aims to examine improving students' mathematical understanding through Think Talk Write learning strategy. The method is a quasi experiment with experimental class research design and the pretest-posttest control class. The experimental class implemented the Think Talk Write learning strategy and the control class by direct learning model. The population of this study is a fourth grader of one elementary school in Bandung. The sample in this research is 50 students, two classes. The instrument used in data collection is a test of the mathematical understanding ability of the description form. The result data were $N$ gain score analyzed by using independent-test t-test and Mann-Whitney test. From this research, obtained the conclusion, improving students' mathematical understanding ability who get learning with Think Talk Write strategy is better than students who gain learning by direct learning.
\end{abstract}

Keywords: Mathematical Understanding, Think Talk Write learning strategy and direct learning model. 


\section{PENDAHULUAN}

Matematika adalah suatu alat untuk mengemban salah satu penunjang yang sangat penting dalam kehidupan. Matematika merupakan ilmu universal yang mendasari perkembangan teknologi modern, mempunyai peran penting dalam berbagai disiplin ilmu dan memajukan daya pikir manusia.

National Council Of Teacher Of Mathematics (NCTM) tahun 2000 telah menetapkan lima kemampuan dasar dalam pembelajaran matematika. Adapun lima keterampilan proses yang harus dimiliki siswa melalui pembelajaran matematika yang tercakup dalam proses, yaitu (1) komunikasi matematis (mathematical communication), (2) penalaran dan pembuktian matematis (mathematical reasoning and proof), (3) pemecahan masalah matematis (mathematical problem solving), (4) koneksi matematis (mathematical connection), dan (5) matematis (mathematical representation).

Mencermati beberapa uraian di atas, maka kemampuan pemahaman matematis merupakan kemampuan siswa untuk memahami pelajaran matematika lebih lanjut. Siswa akan kesulitan dalam menyelesaikan persoalan tanpa memiliki pemahaman konsep, karena suatu persoalan dapat diselesaikan ketika siswa telah memahami permasalahan tersebut dan kemudian berpikir untuk mencari penyelesaiannya. Membangun pemahaman pada setiap kegiatan belajar matematika akan memperluas pengetahuan matematika yang dimiliki. Semakin luas pengetahuan tentang ide atau gagasan matematika yang dimiliki semakin bermanfaat dalam menyelesaikan suatu masalah yang dihadapi.

Tujuan dari suatu kegiatan pembelajaran adalah tercapainya kemampuan yang telah ditetapkan. Taksonomi Bloom menjelaskan enam tahapan pembelajaran yang dimulai dari mengingat, memahami, sampai mencipta. Pencapaian yang dimaksud dapat terlaksana apabila belajar matematika dengan pemahaman. Dalam belajar bidang-bidang eksakta dan kompleks seperti mata pelajaran matematika diperlukan kemampuan pemahaman matematis, yang memegang peranan esensial (Turmudi, 2009).

Kemampuan pemahaman matematis adalah salah satu tujuan penting dalam pembelajaran matematika, memberikan pengertian bahwa materi-materi yang diajarkan kepada siswa bukan hanya hafalan, namun lebih mengerti akan konsep materi pelajaran itu sendiri. 
Berdasarkan uraian diatas, dapat dilihat betapa pentingnya kemampuan pemahaman matematis siswa dalam proses pembelajaran matematika. Untuk meningkatkan kemampuan pemahaman matematis dapat dilakukan dengan berbagai cara. Banyak metode, strategi, ataupun model pembelajaran yang dapat diterapkan untuk meningkatkan kemampuan pemahaman matematis. Salah satunya adalah menerapkan pembelajaran dengan strategi Think Talk Write.

Strategi yang diperkenalkan oleh Hinker \& Laughfin (1996) pada dasarnya dibangun melalui berpikir, berbicara dan menulis. Think Talk Write (TTW) adalah strategi yang memfasilitasi latihan berbahasa secara lisan dan menulis bahasa tersebut dengan lancar.

Teori yang mendasari strategi TTW adalah teori kontruktivisme dari Piaget. Piaget (Dahar, 2002) menyatakan terdapat tiga aspek perkembangan intelektual yaitu: 1) struktur, Piaget berpendapat bahwa ada hubungan fungsional antara tindakan fisik, tindakan mental, dan perkembangan berpikir logis siswa; 2) Isi, adalah pola perilaku anak yang khas yang tercermin pada respon yang diberikannya terhadap berbagai masalah atau situasi yang dihadapinya; 3) Fungsi, menurut Piaget perkembangan intelektual didasarkan pada dua fungsi yaitu organisasi dan adaptasi. Adaptasi terhadap lingkungan dilakukan melalui dua proses, yaitu asimilasi dan akomodasi. Dalam proses akomodasi seseorang memerlukan modifikasi struktur mental yang ada dalam mengadakan respon terhadap tantangan lingkungannya.

Strategi TTW dimulai dengan bagaimana siswa memikirkan penyelesaian suatu tugas (masalah), kemudian diikuti dengan menggunakan hasil pemikirannya, dan akhirnya melalui diskusi siswa dapat menuliskan kembali hasil pemikiran tersebut. keuntungan lain, pengguna strategi TTW dalam pembelajaran adalah: (1) mempercepat kemahiran dalam menggunakan strategi, (2) membantu siswa mempercepat pemahaman, (3) memberi kesempatan pada siswa mendiskusikan suatu strategi penyelesaian untuk mempercepat problem solving maupun reasoning. Baradoy, 1993 (dalam Taufiq, 2014).

Strategi Think Talk Write dimungkinkan dapat membantu meningkatkan kemampuan pemahaman matematis siswa. Strategi ini terdiri dari tiga fase yaitu fase think, fase talk dan fase write. Pada fase think siswa diberikan masalah yang terdapat pada lembar aktivitas siswa, kemudian siswa membaca permasalahan 
dan memikirkan kemungkinan jawaban dari permasalahan tersebut. Pada fase ini siswa bekerja secara individu, sehingga pada fase ini diharapkan siswa tertantang oleh peramasalahan yang diberikan. Pada fase ini siswa berusaha sendiri mengkontruksi sendiri pengetahuannya untuk menyelesaikan permasalahan tersebut. Fase kedua adalah fase talk, pada fase ini siswa mendiskusikan apa yang didapat pada fase think, siswa bekerja secara berkelompok dan diharapkan dapat berdiskusi. Fase ketiga adalah fase write, pada fase ini siswa bekerja secara individu lagi, dan diharapkan siswa dapat mengkontruksi sendiri ide-ide yang didapat dari hasil diskusinya. Pada fase ini diharapkan akan tumbuh daya kreativitas siswa dalam menuangkan ide-ide yang didapat pada fase talk dan menuliskan dengan bahasa sendiri apa yang diperolehnya.

\section{METODE PENELITIAN}

Jenis penelitian ini adalah kuasi eksperimen. Populasi pada penelitian ini adalah siswa Sekolah Dasar Negeri Bandung, dengan sampel dalam penelitian adalah siswa kelas IV salah satu SD Negeri di Bandung. Pemilihan kelas IV didasarkan atas pertimbangan bahwa siswa kelas IV dianggap peneliti memenuhi prasyarat yang cukup untuk menjadi objek penelitian.

Tujuan penelitian ini adalah menguji strategi Think Talk Write terhadap kemampuan pemahaman matematis siswa dengan menggunakan desain penelitian (Russefendi, 2010) seperti berikut:

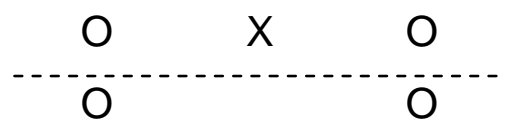

Keterangan:

$\mathrm{O}=$ Pretes dan posttest (tes kemampuan pemahaman matematis).

$\mathrm{X}=$ Perlakuan (strategi Think Talk Write).

Untuk memperoleh data dalam penelitian ini instrumen yang digunakan peneliti dalam penelitian ini yaitu dengan menggunakan tes tertulis, yaitu pretest dan posttest. Tes untuk mengukur kemampuan pemahaman matematis siswa ini berupa soal-soal uraian. Penyusunan soal diawali dengan pembuatan kisi-kisi soal, kemudian menulis soal dan alternatif jawaban. Skor yang diberikan pada setiap jawaban siswa ditentukan berdasarkan pedoman penskoran. 


\section{HASIL PENELITIAN}

\section{Hasil Penelitian dan Analisis Data}

Data penelitian yang bersifat kuantitatif diperoleh melalui data hasil tes kemampuan pemahaman matematis siswa. Dalam penelitian ini, dilibatkan (50) orang siswa sebagai subjek penelitian yang berasal dari salah satu SD Negeri di kota Bandung. Sebanyak (25) siswa pada kelas eksperimen yang memperoleh pembelajaran dengan strategi Think Talk Write dan 25 siswa pada kelas kontrol yang memperoleh pembelajaran matematika dengan menggunakan pembelajaran langsung .

Perhitungan kemampuan pemahaman matematis siswa pada penelitian ini dilihat dari pencapaian siswa sebelum dan sesudah diberikan perlakuan. Adapun data kemampuan yang dianalisis meliputi, skor pretest, skor postest kemampuan pemahaman matematis. Selanjutnya berdasarkan skor pretest dan posttest ditentukan skor pencapaian kemampuan pemahaman matematis pada kelas eksperimen dan kelas kontrol. Untuk melihat pencapaian skor kemampuan pemahaman matematis siswa, tahapan yang dilakukan adalah dengan melakukan perhitungan rata-rata pretest dan posttest kedua kelas. Analisis lebih lanjut perhitungan pencapaian skor kemampuan pemahaman matematis ini dilakukan berdasarkan skor posttest kemampuan pemahaman matematis siswa yang diperoleh dari kelas eksperimen yang memperoleh pembelajaran dengan strategi Think Talk Write dan skor posttest kemampuan pemahaman matematis siswa kelas kontrol yang memperoleh pembelajaran dengan pembelajaran langsung. Berikut ini merupakan deksripsi hasil skor pretest dan posttest kemampuan pemahaman matematis siswa kelas eksperimen dan kelas kontrol.

Tabel 1

Deskripsi skor Pretest dan Postest Kemampuan Pemahaman Matematis

\begin{tabular}{|c|c|c|c|c|c|c|c|}
\hline \multirow{2}{*}{ NO } & \multirow{2}{*}{ NAMA } & \multicolumn{2}{|c|}{ Strategi Think Talk Write } & \multicolumn{3}{c|}{ Pembelajaran langsung } \\
\cline { 3 - 8 } & & $\begin{array}{c}\text { skor } \\
\text { pretest }\end{array}$ & $\begin{array}{c}\text { skor } \\
\text { posttest }\end{array}$ & N-gain & $\begin{array}{c}\text { Skor } \\
\text { pretest }\end{array}$ & $\begin{array}{c}\text { Skor } \\
\text { posttest }\end{array}$ & N-gain \\
\hline 1 & $\mathrm{AX} 1$ & 38 & 79 & 0,21 & 21 & 63 & 0,19 \\
\hline 2 & $\mathrm{AX} 2$ & 29 & 71 & 0,2 & 38 & 67 & 0,14 \\
\hline
\end{tabular}


JURNAL TUNJUK AJAR, Volume 1, Nomor 1, 2018

ISSN: 2615-062X

https://doi.org/10.31258/ita.v1i1.57-72

\begin{tabular}{|c|c|c|c|c|c|c|c|}
\hline 3 & AX3 & 38 & 75 & 0,19 & 38 & 63 & 0,12 \\
\hline 4 & AX4 & 42 & 88 & 0,23 & 46 & 83 & 0,19 \\
\hline 5 & AX5 & 42 & 67 & 0,13 & 50 & 63 & 0,07 \\
\hline 6 & AX6 & 33 & 75 & 0,2 & 50 & 67 & 0,09 \\
\hline 7 & AX7 & 33 & 71 & 0,18 & 42 & 79 & 0,19 \\
\hline 8 & AX8 & 29 & 63 & 0,16 & 38 & 71 & 0,16 \\
\hline 9 & AX9 & 42 & 79 & 0,19 & 54 & 83 & 0,16 \\
\hline 10 & $A \times 10$ & 29 & 67 & 0,18 & 50 & 71 & 0,11 \\
\hline 11 & $A X 11$ & 38 & 79 & 0,21 & 33 & 63 & 0,14 \\
\hline 12 & $\mathrm{AX} 12$ & 33 & 71 & 0,18 & 38 & 63 & 0,12 \\
\hline 13 & $A \times 13$ & 46 & 83 & 0,19 & 29 & 79 & 0,24 \\
\hline 14 & $\mathrm{AX14}$ & 29 & 71 & 0,2 & 29 & 63 & 0,16 \\
\hline 15 & $\mathrm{AX} 15$ & 38 & 67 & 0,14 & 33 & 67 & 0,16 \\
\hline 16 & $A \times 16$ & 46 & 75 & 0,15 & 29 & 75 & 0,22 \\
\hline 17 & $\mathrm{AX} 17$ & 42 & 92 & 0,25 & 29 & 67 & 0,18 \\
\hline 18 & AX18 & 33 & 75 & 0,2 & 25 & 71 & 0,21 \\
\hline 19 & AX19 & 42 & 75 & 0,17 & 46 & 67 & 0,11 \\
\hline 20 & AX20 & 38 & 75 & 0,19 & 25 & 67 & 0,19 \\
\hline 21 & AX21 & 42 & 92 & 0,25 & 29 & 50 & 0,1 \\
\hline 22 & AX22 & 29 & 71 & 0,2 & 33 & 71 & 0,18 \\
\hline 23 & AX23 & 38 & 67 & 0,14 & 50 & 88 & 0,2 \\
\hline 24 & AX24 & 46 & 83 & 0,19 & 46 & 63 & 0,09 \\
\hline 25 & AX25 & 29 & 71 & 0,2 & 29 & 88 & 0,28 \\
\hline \multicolumn{2}{|c|}{$\mathbf{X}_{\min }$} & 29 & 67 & 0,14 & 21 & 50 & 0,1 \\
\hline \multicolumn{2}{|c|}{$X_{\text {maks }}$} & 42 & 92 & 0,23 & 50 & 88 & 0,28 \\
\hline \multicolumn{2}{|c|}{ Jumlah } & 921 & 1879 & 4,72 & 929 & 1746 & 4 \\
\hline \multicolumn{2}{|c|}{ Rata-rata } & 37 & 75 & 0,19 & 37 & 69,8 & 0,16 \\
\hline \multicolumn{2}{|c|}{ Std Deviasi } & 5,73 & 7,75 & 0,03 & 9,54 & 9,18 & 0,05 \\
\hline
\end{tabular}

Skor pretest dan posttest kemampuan pemahaman matematis di atas dapat digambarkan dalam diagram berikut.

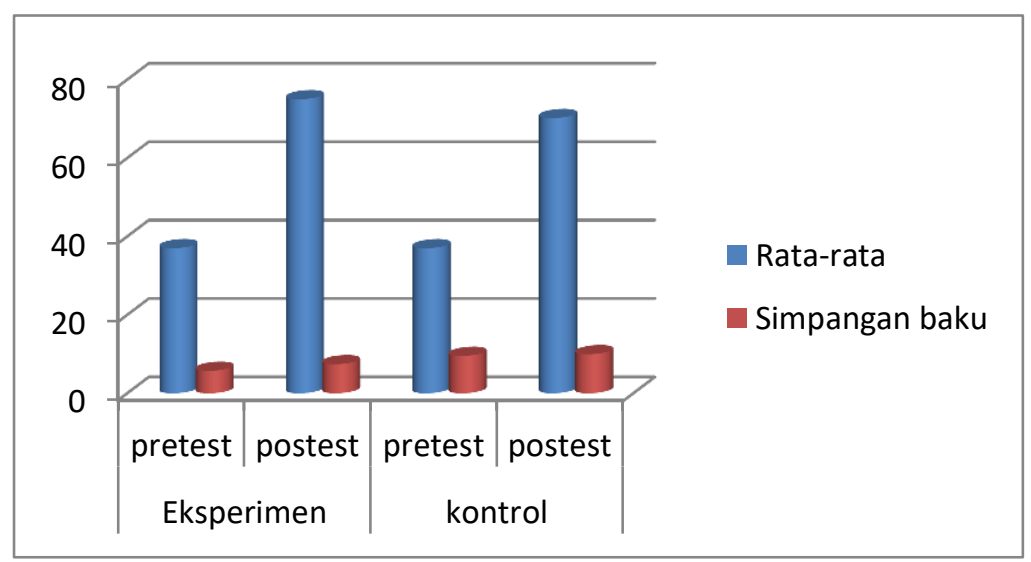

Diagram 1

Skor Pretest dan Posttest kemampuan pemahaman matematis 
Tabel 1 dan diagram 1 di atas memperlihatkan rata-rata skor pretest, posttest dan $\mathrm{N}$-gain kemampuan pemahaman matematis siswa kelas eksperimen dan kelas kontrol. Nilai rata-rata skor pretest kemampuan pemahaman matematis kelas kontrol dan eksperimen sama yaitu sebesar 37. Ini menunjukkan bahwa kemampuan awal kelas eksperimen dan kelas kontrol relatif sama sebelum diberikan perlakuan. Selanjutnya dilihat dari nilai rata-rata skor postest kemampuan pemahaman matematis kelas eksperimen lebih tinggi yaitu 75 dibandingkan dengan nilai rata-rata skor postest kemampuan pemahaman matematis kelas kontrol yaitu sebesar 69,8.

Adapun untuk skor $\mathrm{N}$-gain kemampuan pemahaman matematis, rata-rata skor N-gain kemampuan pemahaman matematis yang diperoleh siswa di kelas eksperimen sebesar 0,19 sedangkan rata-rata skor $\mathrm{N}$-gain kemampuan pemahaman matematis siswa di kelas kontrol adalah 0,16. Klasifikasi tingkat $\mathrm{N}$ gain kemampuan pemahaman matematis di kedua kelas berada pada kategori sama yaitu pada kategori rendah. Selisih rata-rata skor N-gain kemampuan pemahaman matematis siswa di kelas eksperimen yang memperoleh pembelajaran dengan strategi Think Talk Write relatif sama dibandingkan dengan rata-rata skor $\mathrm{N}$-gain kemampuan pemahaman matematis siswa kelas kontrol yang memperoleh pembelajaran dengan pembelajaran langsung. Selisih rata-rata $\mathrm{N}$-gain kemampuan pemahaman matematis yang diperoleh kelas eksperimen dan kelas kontrol adalah sebesar 0,03. Rata-rata ini diperoleh dari jumlah perolehan skor yang didapat siswa dibagi dengan skor ideal kemudian dikalikan dengan $100 \%$.

Berdasarkan skor posttest kemampuan pemahaman matematis siswa tersebut ditentukan pengujian rata-rata pencapaian kemampuan pemahaman matematis. Tahapan pertama sebelum dilakukan analisis lebih lanjut adalah dengan melakukan uji normalitas dan uji homogenitas. Uji normalitas dan homogenitas ini merupakan uji prasyarat dalam menentukan uji yang akan digunakan dalam menganalisis data. Pengujian rata-rata pencapaian kemampuan pemahaman matematis dilakukan berdasarkan skor posttest kemampuan pemahaman matematis yang diperoleh dari kelas eksperimen yang memperoleh pembelajaran dengan strategi Think Talk Write dan skor posttest kemampuan 
pemahaman matematis yang diperoleh dari kelas kontrol yang memperoleh pembelajaran dengan pembelajaran langsung.

Selanjutnya berdasarkan skor pretest dan posttest tersebut ditentukan nilai $\mathrm{N}$-gain. Untuk menjawab rumusan masalah yang telah dikemukakan maka dilakukan analisis data berdasarkan skor N-gain kemampuan pemahaman matematis yang diperoleh siswa. Tahapan pertama sebelum dilakukan analisis lebih lanjut adalah dengan melakukan uji normalitas dan uji homogenitas. Uji normalitas dan homogenitas ini merupakan uji prasyarat dalam menentukan uji yang akan digunakan dalam menganalisis data. Perhitungan terhadap skor N-gain ini dilakukan berdasarkan skor pretest dan posttest kemampuan pemahaman matematis yang diperoleh dari kelas eksperimen yang memperoleh pembelajaran dengan strategi Think Talk Write dan skor pretest-posttest kemampuan pemahaman matematis yang diperoleh dari kelas kontrol yang memperoleh pembelajaran matematika dengan pembelajaran langsung.

\section{PEMBAHASAN HASIL PENELITIAN}

Pembahasan hasil penelitian didasarkan pada hasil penelitian dan analisis data hasil penelitian. Faktor-faktor yang dilihat dalam penelitian ini yaitu mengenai peningkatan kemampuan pemehaman dan siswa yang memperoleh pembelajaran dengan Think Talk Write dan pembelajaran langsung.

\section{Deskripsi penerapan pembelajaran dengan strategi Think Talk Write.}

Pembelajaran dengan strategi Think Talk Write yang diterapkan di kelas eksperimen melalui beberapa langkah: yaitu (1) Pada tahap think siswa membaca teks berupa permasalahan-permasalahan. Dalam tahap ini siswa secara indivisu memikirkan kemungkinan jawaban. (2) siswa mendiskusikan hasil pemikirannya didalam kelompok (talk). (3) menuliskan hasil diskusi pada lembar kerja yang disediakan.

Pada pertemuan pertama, semua fase berjalan namun kurang kondusif dikarenakan siswa belum terbiasa melaksanakan pembelajaran dengan menggunakan lembar aktivitas siswa yang diberikan guru. disamping itu, butuh waktu yang cukup lama dalam menjelaskan pembelajaran yang akan dilalui dan mengorganisasikan siswa. Masih ada siswa yang agak malas untuk berdiskusi 
dalam kelompoknya. guru berupaya membimbing kelompok-kelompok untuk bekerja sama dalam memecahkan masalah yang diberikan. Dalam kegiatan kelompok peneliti menemukan bahwa partisipasi siswa dalam kelompok masih kurang, oleh karena itu perlu diberikan perhatian lebih besar sehingga semua anggota dalam setiap kelompok terlibat aktif berpartisipasi dan bekerja dalam kelompoknya. Selain itu, pembelajaran dengan strategi Think Talk Write merupakan strategi pembelajaran yang baru bagi siswa di tempat penelitian, ini juga menjadi salah satu sebab mengapa kemampuan siswa belum bisa berkembangan secara maksimal. siswa memerlukan waktu yang relatif lama untuk beradaptasi dengan pembelajaran dengan strategi Think Talk Write ini.

Pertemua kedua, pembelajaran sudah mulai berjalan efektif karena siswa sudah mengetahui bagaimana pembelajaran yang akan dilaksanakan. Siswa mulai aktif berdiskusi dalam kelompok. Siswa juga sudah mulai bertanggungjawab atas presentasi kelompok, meskipun ada beberapa siswa yang kurang memperhatikan.

Pertemuan ke-3 sampai ke-5, pembelajaran sudah berjalan baik. Lebih baik dari pertemuan ke-1 dan ke-2. Siswa aktif berdiskusi menyampaikan pendapat dikelompok, dan mempresentasikan hasil diskusi dengan baik. Pada pertemuan terakhir, guru memberikan apresiasi kepada setiap kelompok yang sudah berpartisipasi selama pembelajaran dan meminta maaf untuk setiap kesalahan yang diperbuat. Guru memotivasi siswa untuk mempelajari kembali materi yang sudah didapatkan sebagai persiapan posttest.

\section{Deskripsi penerapan pembelajaran dengan model pembelajaran langsung.}

Menurut Joyce, Weil with Shower (2004) mengemukakan:

"The learn pembelajaran langsung has been used by researchers to refer to a pattern of teaching which consists of the teeacher's explaining a new concept or skill to a large group of students, having them test their understanding by practicing under teacher direction and encouraging them to continue to practice attheir sarts under teacher guidance (guided practice)."

Istilah pengajaran langsung telah digunakan untuk peneliti untuk mengacu pada suatu mengajar yang terdiri dari guru menjelaskan suatu keterampilan atau konsep baru dalam kelompok besar siswa, menguji pemahaman mereka dengan 
praktek, dibawah arahan guru dan mereka melanjutkan untuk praktek pada tempat duduk mereka dibawah bimbingan guru (praktek yang dipandu).

Pembelajaran langsung (DI) juga dikenal dengan sebutan pengajaran aktif (Active Teaching) atau pengajaran seluruh kelas (Whole-Class Teaching). Joyce, Weil \& Calhoun (2009) menyatakan ada lima langkah pembelajaran langsung, yaitu: 1) Orientas, 2) Presentasi, 3) Praktik dibawah bimbingan, 4) Praktik mandiri, dan 5) Praktik yang terkoordinir.

Pada pertemuan pertama, langkah pembelajaran sudah terlaksana dengan baik namun kurang efektif. Saat guru menjelaskan pelajaran di depan kelas, masih ada siswa yang bercerita dan bermain. Siswa kurang merespon pertanyaan dan soal yang diberikan guru di depan kelas. Sehingga pada praktik mandiri, siswa mengalami kendala dalam menyelesaikan latihan yang diberikan guru.

Pertemuan ke-2 sampai ke-5, pembelajaran berlangsung kondusif. Siswa mendengar dan menyimak serta ikut berpartisipasi dalam kegiatan pembelajaran. Siswa merespon pertanyaan yang diberikan guru. Siswa bisa mengerjakan latihan yang diberikan guru dengan baik.

\section{Kemampuan Pemahaman Matematis}

Kemampuan pemahaman matematis merupakan salah satu kemampuan yang harus dimiliki oleh siswa karena berpengaruh terhadap kemampuan matematis lainnya. Tujuan penelitian ini adalah untuk mengetahui apakah peningkatan kemampuan matematis siswa yang memperoleh pembelajaran dengan strategi Think Talk Write lebih baik daripada siswa yang memperoleh pembelajaran langsung menggunakan skor N-gain.

Berdasarkan temuan hasil penelitian menunjukkan rata-rata skor pretest kelas Think Talk Write dan kelas pembelajaran langsung tidak berbeda. Artinya, kemampuan awal kedua kelas sama. Hal ini dibuktikan dengan hasil uji statistik yang menyimpulkan bahwa tidak terdapat perbedaan skor pretest kemampuan pemahaman matematis siswa di kelas eksperimen dan kelas kontrol.

Sedangkan temuan skor postest kemampuan pemahaman matematis diketahui nilai rata-rata kelas eksperimen relatif lebih tinggi dibandingkan dengan kelas kontrol. Setelah dibuktikan dengan pengujian statistik diperoleh kesimpulan bahwa pencapaian kemampuan pemahaman matematis yang memperoleh pembelajaran dengan strategi Think Talk Write lebih baik dibandingkan 
kemampuan pemahaman matematis siswa yang memperoleh pembelajaran dengan pembelajaran langsung.

Adapun untuk skor $\mathrm{N}$-gain kemampuan pemahaman matematis siswa yang memperoleh pembelajaran dengan strategi Think Talk Write adalah 0,19, sedangkan rata-rata skor $\mathrm{N}$-gain kemampuan pemahaman matematis siswa yang memperoleh pembelajaran dengan pembelajaran langsung adalah 0,16. Selisih rata-rata skor $\mathrm{N}$-gain kemampuan pemahaman matematis pada kedua kelas tersebut relatif tidak jauh berbeda yaitu sebesar 0,3. Namun berdasarkan hasil uji statistik dengan independent $t$-test pada taraf signifikansi $\alpha=0,05$ menunjukkan terdapat perbedaan yang signifikan. Oleh karena nilai rata-rata skor $\mathrm{N}$-gain kemampuan pemahaman matematis siswa kelas Think Talk Write lebih tinggi dibandingkan dengan kelas pembelajaran langsung, dengan demikian dapat disimpulkan bahwa peningkatan kemampuan pemahaman matematis siswa di kelas eksperimen yang memperoleh pembelajaran dengan strategi Think Talk Write lebih baik dibandingkan siswa di kelas kontrol yang memperoleh pembelajaran langsung.

Berdasarkan uraian di atas menunjukkan bahwa pembelajaran dengan strategi Think Talk Write dapat meningkatkan kemampuan pemahaman matematis siswa di sekolah dasar. Hal ini diduga karena dalam pembelajaran dengan menggunakan strategi Think Talk Write, siswa lebih memahami konsep matematis secara sistematis dikarenakan lembar aktivitas siswa dapat menuntun siswa pada konsep yang dituju. Sesuai dengan yang dinyatakan Santrock (2010) yang menyebutkan bahwa dalam sebuah kelompok belajar bersama, siswa mengajarkan sesuatu kepada siswa lainnya, mereka cenderung belajar lebih mendalam. Belajar di kelompok dan berdiskusi, memungkinkan siswa dalam membantu siswa untuk lebih aktif dan bisa bertanya tentang materi yang dipelajari tanpa merasa malu. Salah satu kendala dalam proses pembelajaran adalah siswa malu bertanya, takut pertanyaan yang dikemukakan salah. Sehingga materi yang dipelajari tidak dipahami dengan baik. Sementara pada kelas pembelajaran langsung lebih mengutamakan kemandirian dan proses belajar secara individual dalam menggunakan sumber belajar yang mereka punya. Sehingga siswa mencari jawaban secara mandiri. 
Berikut adalah sampel dari jawaban salah satu siswa kelas eksperimen dalam menyelesaikan permasalahan yang diberikan.

\section{Soal:}

Perhatikan gambar kubus berikut!

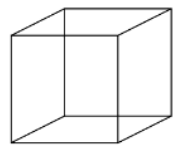

Sebutkan ciri-ciri dari bangun kubus di atas!

Jawaban:

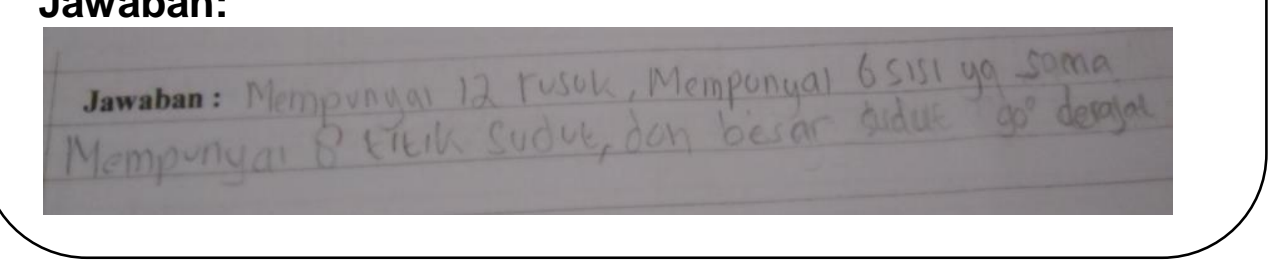

\section{Gambar 2}

Hasil jawaban salah satu siswa di kelas eksperimen

Berdasarkan gambar 1 diatas dapat dilihat bahwa jawaban yang diberikan siswa di kelas eksperimen sudah sangat baik, siswa dapat menyelesaikan soal kemampuan pemahaman matematis dengan baik, siswa menggunakan kalimat yang baik dalam menjawab soal sehingga mudah dipahami. Jawaban yang dikemukakan siswa juga telah memenuhi kriteria maksimal penskoran pemahaman matematis. Penyelesaian yang diberikan siswa sudah menunjukkan bahwa kemampuan pemahaman matematis yang dimiliki siswa sudah baik sehingga dapat memberikan jawaban yang tepat. Sedangkan sampel jawaban salah satu siswa di kelas kontrol adalah sebagai berikut:

Soal:

Perhatikan gambar kubus berikut!

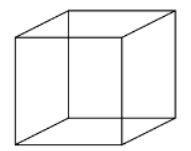

Sebutkan ciri-ciri dari bangun kubus di atas! Jawaban:

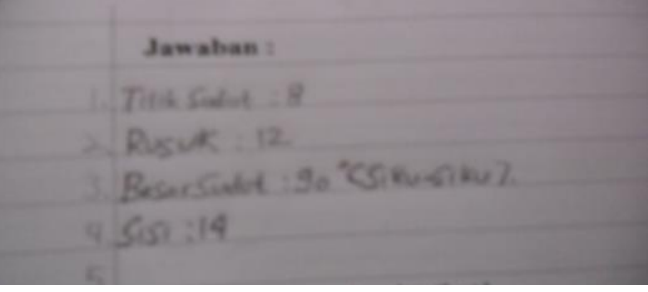

Hasil jawaban salah satu siswa di kelas kontrol 
Hasil jawaban siswa kelas kontrol pada gambar diatas sedikit berbeda dengan jawaban salah satu siswa pada kelas eskperimen. Jawaban yang dikemukakan siswa pada poin terakhir dapat dilihat belum tepat. Hal ini menunjukkan bahwa kemampuan pemahaman matematis siswa pada soal yang diberikan belum menunjukkan pemahaman yang baik.

Perbedaan jawaban siswa pada kelas dengan Think Talk Write diduga disebabkan karena aktivitas pembelajaran. Pada pembelajaran dengan strategi Think Talk Write siswa belajar bersama dalam kelompok dan menemukan sendiri jawaban dari permasalahan yang diberikan. Pada fase kedua "talk", siswa saling memberi pendapat kepada anggota kelompoknya. Hal ini memungkinkan anggota kelompok untuk saling berbagi pengetahuan kepada siswa yang belum memahami materi yang sedang dipelajari, sehingga siswa bisa lebih memahami materi pelajaran melalui berdiskusi. Hal ini sesuai dengan yang kemukakan Johnson \& Johnson (dalam Wibowo, 2009) mengatakan bahwa ketika siswa saling berbagi, saling mengajarkan pengetahuan kepada teman lainnya maka akan membantu pencapaian tingkat prestasinya. Pendapat yang sama juga dikemukan oleh Kosko \& Wilkins (2010) mengemukakan bahwa diskusi antar siswa adalah kesempatan dalam memperdalam pemahaman konsep. Sejalan dengan apa yang dikemukakan oleh Witherell (2010) bahwa siswa yang ditempatkan dalam suatu kelompok dalam jangka waktu tertentu akan membentuk suatu ikatan dan kemudian terlibat dalam percakapan mengenai konsep matematika. Sedangkan pada pembelajaran langsung menunjukkan bahwa jawaban yang diberikan oleh siswa belum sempurna. Jawaban yang diberikan oleh siswa secara keseluruhan belum menunjukkan pemahaman yang baik. Hal ini diduga karena proses pembelajaran yang berlangsung secara individual sehingga siswa cenderung hanya mendengarkan dan menghafal konsep yang diajarkan, ketika diberikan soal yang berbeda dengan contoh soal siswa terlihat kesulitan untuk menyelesaikannya.

Berdasarkan proses pembelajarannya, pembelajaran dengan menggunakan strategi Think Talk Write adalah pembelajaran yang menitikberatkan kepada keaktifan siswa dalam membangun pengetahuan pemahamannya. Hal ini sejalan dengan pendapat Piaget (Sutawidjaja dan Dahlan, 2011) bahwa keinginan anak mendorong dia untuk aktif mengkontruksi informasi baru di dalam pikirannya, 
sehingga akan terjadi proses asimilasi dan akomdasi pada tahap berpikir siswa yang berakibat tingkat pemahaman siswa semakin bertambah dan memiliki retensi yang lebih kuat.

\section{SIMPULAN DAN SARAN}

\section{Simpulan}

Berdasarkan rumusan masalah, hasil analisis data, dan pembahasan hasil penelitian dapat disimpulkan bahwa Peningkatan kemampuan pemahaman matematis siswa yang memperoleh pembelajaran dengan strategi Think Talk Write lebih baik daripada siswa yang memperoleh pembelajaran matematika dengan model pembelajaran langsung.

\section{Saran}

Berdasarkan hasil analisis dan pembahasan sebelumnya, maka berikut ini penulis mengemukakan beberapa saran yang dapat dipertimbangkan untuk pembelajaran selanjutnya.

1. Penerapan pembelajaran dengan strategi Think Talk Write yang dikelola dengan baik oleh guru dapat meningkatkan kemampuan pemahaman dan representasi matematis siswa, sehingga strategi Think Talk Write dapat menjadi alternatif bagi pembelajaran matematika disekolah dasar dalam meningkatkan kemampuan pemahaman matematis dan kemampuan matematis lainnya.

2. Bahasan yang dikembangkan dalam penelitian ini terkait dengan materi bangun ruang sederhana. Untuk penelitian lebih lanjut, dapat dilakukan penelitian lanjutan untuk materi bangun ruang dijenjang yang lebih tinggi atau pada materi matematika lainnya.

3. Penelitian ini dilakukan untuk melihat pencapaian dan peningkatan kemampuan pemahaman matematis. Untuk penelitian lebih lanjut, penelitian dapat dilakukan untuk melihat peningkatan kemampuan matematis lainnya.

\section{DAFTAR PUSTAKA}

Arikunto,S. 2012 Dasar-dasar Evaluasi pendidikan. Jakarta: Bumi Aksara Asma,N. 2006. Model pembelajaran kooperatif. Jakarta: Deppenas 
Cai,J.L,\& Jakabcsin.M.S. 1996. The Role Of Open-Ended Task And Holistic Scoring Rubrics: Assessing Students' Mathematical Reaseoning Communicatiion. Communication In Mathematics K-12 And Beyond Virginia NCTM.

Creswell. 2012. Educational Research. Planning, Conducting, And Evaluating Quantitative And Qualitative Research. University of Nebraska-Lincoln : Pearson

Dahlan.J.A 2011. Materi pokok analisis kurikulum matematika. Jakarta: Universitas Terbuka.

Depdiknas. 2006. Kurikulum 2006 : Standar kompetensi, mata pelajaran fisika, sekolah menengah atas dan Madrasah Aliyah, Jakarta: Depdiknas.

Hake, R.R. 1999. Analyzing change/ Gain Score (online). Tersedia http://www.physics.indiana.edu/ sdi/AnalyzingChange-Gain.pdf.

Huinker, D. dan Laughlin, C. 1996. "Talk your way into writing". Dalam communication in mathematicss k-12 and beyond, 1996 year book. National Council of Teachers of Mathematics.

Hwang, W.Y, Chen N.S, Dung, J.J, \& Yang, Y.L. (2007). Multiple representation skills and creativety effect on mathematical problem solving using a multimedia whiteboard system . Educational Technology and Society. Vol 10 no 2, PP $191-212$.

Joyce, B. Weil \& Calhoun, E. 2009. Model of teaching. New jersey: Prentice Hall, Inc.

Joyce, B. Weil \& Calhoun, E. 2009. Model of teaching (model-model pengajaran). Terj. Yogyakarta: Pustaka Pelajar.

National Council of Teachers of Mathematics. 2000. Principles and standards for school mathematics.USA: NCTM.

Russefendi. 2005. Dasar-dasar penelitian pendidikan dan bidang eksakta lainnya (edisi revisi) Bandung. Tarsito.

2006. Pengantar kepada membantu guru mengembangkan kompetensinya dalam pengajaran matematika untuk meningkatkan CBSA. Bandung. Tarsito.

2010. Dasar-dasar penelitian pendidikan dan bidang non eksakta lainnya. Bandung: Tarsito.

Salkind, G.M \& Hjalmarson, M. 2007. Mathematical representation. 
Sutawidjaja \& Dahlan. 2011. Pembelajaran matematika. Jakarta: Universitas Terbuka.

Sternberg.R.J. 2008. Psikologi kognitif. Yogyakarta. Pustaka pelajar.

Taufiq. 2014. Meningkatkan kemampuan komunikasi dan pemecahan masalah serta disposisi matematik siswa smp melalui pendekatan kontekstual dan strategi think talk write. Tesis pada Universitas Pendidikan Indonesia. Tidak diterbitkan

Turmudi 2009. Taktik dan strategi pembelajaran matematika : Referensi untuk guru smk mahasiswa dan umum . Jakarta. PT. Leuser Cita Pustaka.

Wahyudin 1999. Kemampuan guru matematika. calon guru matematika dan siswa dalam mata pelajaran matematika. Disertasi doctor pada SPs UPI Bandung. Tidak diterbitkan.

Wahyudin. 2013 Matematika dasar pengetahuan bermuatan pedagogis. Bandung. Mandiri 